додатковими пропозиціями по взаємообміну враженнями та думками 3 приводу не тільки шкільного життя, а й різнопланового об'єднання довколо найвигадливіших вікових зацікавлень - це, в подальшому, додасть учням впевненості, дозволить гнучко реагувати на нестандартні ситуації безмежного світу соціальних мереж і забезпечить вмотивоване ставлення до необхідного повсякчасного самоаналізу при ефективному проведенні комунікаційного режиму віртуального діалогу онлайн не тільки 3 однолітками, а й без винятку 3 різноманітними віковими групами населення. Таким чином, «вмотивована соціалізація» в сучасних умовах дистанційного навантаження допомагає осягнути весь комплекс виховних ускладнень та підкреслює навчальний наголос на тому, як потрібно тримати зацікавлений та доброзичливий зв'язок на відстані.

DOI https://doi.org/10.30525/978-9934-26-114-5-21

\title{
ОСОБЛИВОСТІ ОРГАНІЗАЦЇ̈ ВИХОВНОГО ПРОЦЕСУ КУРАТОРОМ АКАДЕМІЧНОЇ ГРУПИ ВИЩОГО НАВЧАЛЬНОГО ЗАКЛАДУ
}

\author{
Кривов'яз О. С. \\ здобувач $\mathrm{PhD}$, \\ асистент кафедри біологічної та медичної хімї \\ імені академіка Г. О. Бабенка \\ Івано-Франківський національний медичний університет \\ Нечитайло Л. Я. \\ кандидат біологічних наук, \\ асистент кафедри біологічної та медичної хімї \\ імені академіка Г. О. Бабенка \\ Івано-Франківський національний медичний університет \\ м. Івано-Франківськ, Украӥна
}

Процес соціалізації студента у вищому навчальному закладі здійснюється через навчання та виховання. Виховання виконує основну функцію, відповідаючи за цілеспрямоване формування особистості 3 метою підготовки іiі до активної участі в усіх різновидах життєдіяльності суспільства [1,с.152].

Виховна робота завжди $є$ невід'ємною частиною підготовки фахівців із вищою освітою, особливо коли мова йде про підготовку 
майбутніх лікарів. Важлива роль в питаннях виховання студентства належить куратору. На сьогодні робота куратора у вищому навчальному закладі направлена на вирішення конкретного завдання створення оптимальних умов для саморозвитку особистості студента.

Ефективність навчально-виховної роботи залежить від його діяльності. Саме куратори можуть стати ефективними посередниками між суб'єктами освітньо-виховного процесу (виступає основним осередком у стосунках професорсько-викладацького складу, ректорату зі студентами і їх батьками) [2, с. 83 ].

Водночас, куратор бере активну участь у вихованні студентівмедиків. Він вміло підтримує взаємини з визначеною групою студентів впродовж тривалого періоду, створюючи певну виховну систему академічної групи. Завдяки постійному спілкуванні зі студентами академічної групи, педагог вивчає кожну особистість, що допомагає йому впливати як на колектив, так і на окремого студента. Від організаторських та особистісно-професійних якостей куратора залежить формування професійного та особистісного становлення майбутніх спеціалістів i, особливо, фахівців медичного спрямування [3, с. 45]. Саме тому дана тема є актуальною.

Нашою метою $є$ визначення ролі куратора академічної групи в організації виховної роботи вищого навчального закладу.

Кураторство це різновид виховної роботи з студентами. Наставники повинні вивчати інтереси студентів, долучати їх до різних форм позааудорної роботи та мотивувати до процесу навчання.

3 метою вивчення ролі кураторів у формуванні професійних інтересів майбутніх медиків, нами було проведено опитування академнаставників. Зокрема, було запропоновано ряд запитань:

1. Як часто ви проводите виховні години зі студентами кураторської групи?

2. Чи володієте інформацією про кожного студента групи?

3. Чи враховуєте інтереси та побажання студентів при плануванні виховних заходів?

4. Які форми та методи роботи, спрямовані на професійне виховання студента, використовуєте?

5. Чи узгоджуєте планування виховних заходів 3 іншими кураторами груп?

Результати анкетування показали, що куратори академічних груп чітко працюють згідно складеного плану виховних заходів. Варто зазначити, що часто їхня діяльність обмежується цими заходами.

На нашу думку, варто ще й прислухатись до пропозицій студентів щодо виховних заходів. Вони можуть висловлювати різні побажання. 86 
Наприклад: а) збільшення кількості тематичних зустрічей із клінічними спеціалістами, які працюють в різних галузях медицини, б) урізноманітнити проведення тренінгів чи вебінарів тощо. Це сприятиме розширенню їх кола інтересів.

Важливим питанням залишається компетентністний підхід куратора академічних груп різних курсів. Робота наставника відрізнятиметься за змістом, формами та методами, вимагатиме індивідуального підходу до студентів різних вікових груп. Виховна робота куратора медичного вищого навчального закладу спрямована на залучення студентів до участі в культурно-освітній, спортивно-оздоровчій та інших видах діяльності, безпосередній участі в реалізації заходів, що проводяться у навчальному закладі.

Студенти I-го та II-го курсів найбільше потребують уваги куратора. Вони проходять адаптаційний період у новому навчальному середовищі. На цьому етапі куратор повинен допомогти студентам пристосуватись до нових умов. Слід звернути увагу на кожну особистість, уподобання, психологічний стан, сформувати колектив академічної групи, ознайомити 3 історією, традиціями, правилами навчального закладу; ознайомити 3 системою оцінювання знань, проінформувати про нормативні правила навчання та правилами поведінки на кафедрах та гуртожитку, про діючі гуртки, студії, клуби університету, надати інформацію про міські та університетські бібліотеки, про наявність комп'ютерних класів, мережі Internet та правила доступу до них, здійснювати контроль за дисципліною та успішністю студентів [4, с. 70].

Кураторам старших курсів (III- IV) необхідно залучати студентів до науково - дослідницької роботи клінічних кафедр, приймати участь у конференціях, конгресах, науково-методичних семінарах, формувати навички роботи 3 різними категоріями населення, сприяти зростанню інтересу у студентів до здобуття відповідних професійних знань та розвитку їх професійних здібностей. Важливим завданням куратора є моніторинг успішності та відвідуваності занять студентами академічної групи [5, с. 10].

Адаптація студентів різних курсів має суттєві відмінності. Вона відрізняється за ступенем складності, віковими особливостями та підходами.

Проаналізувавши роль кураторів різних академічних груп, варто відзначити, що вони повинні гармонійно поєднувати процес виховання та формування професійних якостей майбутнього медика, враховуючи культурні, духовні, моральні особливості студентів. 


\title{
Література:
}

1. Череднік Д.Л. Особливості організації виховного процесу в сучасних умовах. Сучасні аспекти виховання студентської молоді: матеріали всеукраїнської наук.-прак. конф. (Харків, 19-20 березня 2009p.). Харків, 2009. С. 152-153.

2.Лугова Л.О., Семененко Ю.І. Роль викладача клінічної кафедри в організації виховної роботи зі студентами медичного вищого навчального закладу. Сучасні підходи до вищої медичної освіти в Украӥні: матеріали XIV всеукраїнської наук.-прак. конф. присвяч. 60-річчю ТДМУ (Тернопіль, 18-19 травня 2017p.). Тернопіль, 2017. С. 83-84.

3. Ільченко А.А. Роль куратора академічної групи у вищому навчальному закладі. Вісник Актуальні проблеми вищої педагогічної освіти. Серія «Педагогічні науки». 2017. № 144. С. 45-48.

4. Тихонова О.О. Про важливість ролі куратора у формуванні професійної компетентності студентів-медиків. Вісник проблем біологіі і медицини. 2013. Вип. 3. Том 2 (103). С. 70-73.

5. Васильєва М.О. Роль та значення куратора в організації виховної роботи у вищій школі. Проблеми інженерно-педагогічної освіти. 2014. № 42-43. C. 5-10.

6. Третяк О.С. Завдання, функції, принципи, компоненти та стилі роботи куратора академічної групи у вищому навчальному закладі. Вісник Національного університету оборони Украӥни. 2014. № 3(40). C. 159-164.

DOI https://doi.org/10.30525/978-9934-26-114-5-22

\section{ПЕДАГОГІЧНІ АСПЕКТИ ДОЗВІЛЛСВОЇ ДІЯЛЬНОСТІ}

\author{
Мільто Л. О. \\ доктор педагогічних наук, доцент, \\ професор кафедри педагогіки і психології вищої школи \\ Начіональний педагогічний університет імені М. П. Драгоманова \\ м. Київ, Україна
}

Дозвіллєва діяльність $є$ найважливішим компонентом духовнотворчого розвитку особистості, однією з ключових позицій соціальнокультурної політики України. Сьогодні культурно-дозвіллєва діяльність розглядається як інструмент побудови здорового суспільства, елемент розвитку громадянського суспільства, фактор регіонального розвитку та політичних інновацій. 